\title{
Comparative Efficacy of Some Non Systemic Fungicides against Rice Sheath Blight (Thanatephorus cucumeris)
}

\author{
Mohammad Najeeb Mughal*, Mushtaq Ahmed, Sabiya Bashir, Ali Anwar, Serrat un \\ Nissan, Rais Ahmed and Shafeeq Ahmed Hakeem
}

\author{
Division of Plant Pathology, SK University of Agricultural Sciences and Technology of \\ Kashmir, Shalimar, Srinagar-190025, India \\ *Corresponding author
}

\section{A B S T R A C T}

Six fungicides viz., captan $50 \mathrm{WP}$, copper oxychloride $50 \mathrm{WP}$, dodine $65 \mathrm{WP}$, mancozeb75 WP, propineb70 WP and zineb $80 \mathrm{WP}$ were evaluated against rice sheath blight (Thanatephorus cucumeris). The in-vitro evaluation of these fungicides through poisoned food technique at five different concentrations viz., 50, 100, 200, 500 and $1000 \mu \mathrm{g}$ a.i ml ${ }^{-1}$ indicated that mancozeb proved the most effective exhibiting mean mycelial growth inhibition of 95.26 per cent followed by captan and dodine with 93.80 and 93.66 per cent, respectively. Copper oxychloride proved least effective and resulted in only 44.08 per cent

\section{Keywords}

Evaluation, Sheath blight, Fungicides, rice, Thanatephorus cucumeris

\section{Article Info}

Accepted:

21 July 2017

Available Online:

10 September 2017 mean inhibition of mycelial growth. Maximum mean inhibition of sclerotial germination was exhibited by mancozeb $(51.33 \%)$ followed by captan $(45.06 \%)$ while dodine and propineb caused only 41.20 and 33.86 per cent mean inhibition of sclerotial germination, respectively. Copper oxychloride proved least effective causing 2.44 per cent mean inhibition of sclerotial germination only. In field evaluation, three foliar sprays of each fungicide at their recommended concentrations, separately applied at tillering, booting and post flowering stages of rice cultivar K-448 (Jhelum), revealed that mancozeb75 WP was most efficacious and reduced the mean disease incidence and disease intensity from 40.00 and 19.15 per cent in unsprayed check to 18.50 and 6.98 per cent, respectively, and increased the grain yield from $5.10 \mathrm{t} \mathrm{ha}^{-1}$ in unsprayed check to $6.25 \mathrm{t} \mathrm{ha}^{-1}$, providing an increase of 22.54 per cent over control. Captan 50 WP was next in efficiency and resulted in mean disease incidence of 21.50 and mean disease intensity of 8.24 per cent and a mean grain yield of $6.05 \mathrm{t} \mathrm{ha}^{-1}$, providing an increase in grain yield of 18.62 per cent. The other fungicides in order of their decreasing efficacies were dodine $65 \mathrm{WP}$, propanib $70 \mathrm{WP}$ and zineb 80 WP which resulted in mean disease incidence of $24.25,25.25$ and 27.00 per cent, disease intensity of $8.55,9.26$ and 9.72 per cent and a mean grain yield of $5.95,5.80$ and $5.65 \mathrm{t}$ ha- 1 with an increase in grain of $16.66,13.72$ and 10.78 per cent, respectively. Copper oxychloride $50 \mathrm{WP}$ proved least efficacious, exhibiting disease mean incidence of 32.00 per cent and mean disease intensity of 11.99 per cent and a grain yield of $5.45 \mathrm{t} \mathrm{ha}^{-1}$, with lowest increase in grain yield of 6.86 per cent only.

\section{Introduction}

Rice (Oryza sativa L.) is the most important cereal crop of India. It is staple food crop of Jammu and Kashmir where it occupies 261.35 thousand hectare area with an annual production of 5001thousand tonnes in 2011 (Kaloo et al., 2014). The crop is attacked by a number of fungal, bacterial and viral diseases, which inflict heavy yield losses every year. 
Among the fungal diseases, the rice blast (Pyricularia grisea), rice sheath blight (Thanatephorus cucumeris) and brown leaf spot (Helminthosporium oryzae) are most important and potentially damaging in Jammu and Kashmir. Sheath blight of rice has attained the status of a major disease in the recent past from what was described as a minor disease by Ramakrishna (1971). The disease has wide geographic distribution and now occurs throughout the temperate and tropical rice production areas, being most prominent where rice is grown under intense, high fertility production system (Eizenga et al., 2002). Sheath blight of rice was first reported in India by Paracer and Chahal (1963), while from Kashmir it was reported by Mir (1986).

The sheath blight of rice caused by Thanatephorus cucumeris [Anamorph: Rhizoctonia solani Kuhn] is one of the important biological constraints in achieving the stable rice production. The disease can result in yield losses ranging from 20-50 per cent (Rajan, 1987). However, under conditions of heavy severity, yield loss of more than 70 per cent has been reported from Chennai, India (Baby, 1992), and even complete crop failure has also been reported in Vietnam (Ou, 1992).

One of the major causes for the increased incidence of this disease has been ascribed to the introduction and wide spread cultivation of high yielding fertilizers responsive varieties producing maximum number of productive tillers per unit area of field, thus creating conditions of increased relative humidity and prolonged leaf wetness and therefore, making the crop more vulnerable to the attack by the pathogen. The presently cultivated rice varieties do not possess desirable levels of resistance and require support of frequent applications of fungicides. Therefore, an attempt was made to evaluate some non-systemic fungicides against the disease and the results are presented herein.

\section{Materials and Methods}

The fungicide was evaluated against rice sheath blight (T. cucumeris) in-vitro and in the field.

\section{In-vitro evaluation}

The test fungicides were evaluated at 50, 100, 250, 500 and $1000 \mu \mathrm{g}$ a.i $\mathrm{ml}^{-1}$ through poisoned food technique (Carpenter, 1942) using potato dextrose agar medium for their effects on inhibition of mycelial growth and sclerotial germination of Thanatephorus cucumeris. The required concentrations of fungicides were prepared by adding appropriate amount of fungicides to sterilized molten PDA medium in conical flasks. Thirty $\mathrm{ml}$ of such amended PDA was aseptically poured in sterilized Petri plates. A $5 \mathrm{~mm}$ diameter mycelial disc of $T$. cucumeris was aseptically placed in the centre of each Petri plate. Petri plates containing PDA media amended with equal amount of sterilized distilled water and inoculated with mycelial disc of T. cucumeris (5 $\mathrm{mm}$ diameter) served as check. Each treatment was replicated thrice and incubated at $28 \pm 2^{\circ}$ for $48 \mathrm{hrs}$. The comparative efficacy of fungicides was calculated as per cent inhibition of mycelial growth of the test fungus in each treatment as compared to check by the following formula:

Per cent mycelial
Growth inhibition $=-\frac{\mathrm{C}-\mathrm{T}}{\mathrm{C}} \mathrm{C}$

Where

$\mathrm{C}=$ Radial mycelial growth $(\mathrm{mm})$ in check

$\mathrm{T}=$ Radial mycelial growth in the treatment (mm) 
Fungicides were also evaluated against inhibition of sclerotial germination of Thanatephorus cucumeris. The sclerotia of $T$. cucumeris from 7 days old culture were used. Twenty five sclerotia were used in each treatment and each treatment was replicated thrice. The inhibition of sclerotial germination was recorded after 48 hours and percentage of inhibition of sclerotial germination was recorded as per formula given below:

Inhibition of sclerotial Germination $(\%)=$

No. of un-germinated sclerotial

Total no. of sclerotia

\section{Field evaluation}

Thirty-day old seedlings of rice variety 'Jhelum' (K-448) were transplanted in 5 x 2 $\mathrm{m}$ plots in randomized block design replicating the treatments thrice. Three sprays of each fungide at their recommended concentrations were applied separately at maximum tillering, booting and post flowering stages of crop growth. Treatments where only water was sprayed served as check for all the experiments. Observations on disease incidence and disease intensity were recorded ten days after the last spray (Vihol et al., 2009), whereas the observation on grain yield were recorded at harvest and expressed in tonnes per hectare.

\section{Results and Discussions}

Six fungicides were evaluated in vitro for inhibition of mycelium growth and inhibition of sclerotial germination of the pathogen ( $T$. cucumeris).

\section{Effect on mycelial growth inhibition}

The data (Table 1) revealed that all the test fungicides significantly inhibited the mycelial growth at all the test concentrations. On an overall mean basis, mancozeb 75 WP proved most effective exhibiting mean mycelial growth inhibition of 95.26 per cent followed by captan $50 \mathrm{WP}$ and dodine $65 \mathrm{WP}$ with 93.80 and 93.66 per cent mean inhibition of mycelial growth while propineb and zineb caused 83.99 and 78.33 per cent mean inhibition of mycelial growth, respectively. Copper oxychloride proved least effective resulting in only 44.08 per cent mean inhibition of mycelial growth. In general, the efficacy of fungicides varied significantly with change in fungicide concentration. At 50 $\mu \mathrm{g}$ a.i $\mathrm{ml}^{-1}$ concentration, the mean mycelial growth inhibition was 66.83 per cent which increased to $72.06,79.16,92.98$ and 96.56 per cent at 100, 250, 500 and $1000 \mu \mathrm{g}$ a.i ml ${ }^{-1}$ concentrations, respectively.

The highest mycelial growth inhibition at 50 $\mu \mathrm{g}$ a.i $\mathrm{ml}^{-1}$ concentration was exhibited by mancozeb 75 WP exhibiting 88.33 per cent mean mycelial inhibition followed by captan $50 \mathrm{WP}$ and dodine $65 \mathrm{WP}$, each causing 85.00 per cent mean mycelial inhibition while copper oxychloride 50 WP was least efficacious and resulted in only 9.33 per cent mean mycelial inhibition. Similar pattern in efficacy was recorded by all the fungicides at higher concentrations. Mancozeb 75 WP, captan $50 \mathrm{WP}$, dodine $65 \mathrm{WP}$ and propineb 70 WP completely inhibited the mycelial growth at $500 \mu \mathrm{g}$ a.i $\mathrm{ml}^{-1}$ concentration followed by zineb 80 WP with 91.66 per cent mycelial inhibition, while copper oxychloride $50 \mathrm{WP}$ caused least mycelial growth inhibition $(66.25 \%)$ at the same concentration.

At $1000 \mu \mathrm{g}$ a.i $\mathrm{ml}^{-1}$ concentration, 100.00 per cent mycelial growth inhibition was again caused by mancozeb $75 \mathrm{WP}$, captan $50 \mathrm{WP}$, dodine $65 \mathrm{WP}$ and propineb $70 \mathrm{WP}$ followed by zineb 80 WP (95.00\%) while copper oxychloride 50 WP was least effective and 
resulted in only 84.41 per cent inhibition at the same concentration.

\section{Effect on inhibition sclerotial germination}

The data (Table 1) revealed that mancozeb 75 WP resulted in highest overall mean inhibition $(51.33 \%)$ of sclerotial germination followed by captan $50 \mathrm{WP}(45.06 \%)$ while dodine $65 \mathrm{WP}$ and propineb $70 \mathrm{WP}$ caused 41.20 and 33.86 per cent mean inhibition of sclerotial germination, respectively. Copper oxychloride $50 \mathrm{WP}$ provided least mean inhibition of sclerotial germination $(2.44 \%)$.

In general, the efficacy of fungicides varied significantly with change in fungicide concentration. At $50 \mu \mathrm{g}$ a.i ml ${ }^{-1}$ concentration, there was no inhibition of sclerotial germination. However, at $100 \mu \mathrm{g}$ a.i $\mathrm{ml}^{-1}$, mean inhibition of sclerotial germination was 9.22 per cent which increased to $28.44,52.22$ and 79.61 per cent at 250, 500 and $1000 \mu \mathrm{g}$ a.i $\mathrm{ml}^{-1}$ concentrations, respectively. The highest mean inhibition of sclerotial germination at $100 \mu \mathrm{g}$ a.i $\mathrm{ml}^{-1}$ concentration was exhibited by mancozeb 75 WP exhibiting 29.33 per cent mean mycelial inhibition followed by propineb $(26.00 \%)$ while no other fungicide was capable of causing any inhibition in sclerotial germination at this concentration.

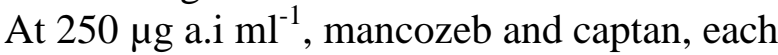
caused highest inhibition of sclerotial germination of 46.67 per cent, followed by dodine $(35.33 \%)$ and propined $(34.67 \%)$.

Similar pattern in efficacy was recorded by all the fungicides at higher concentrations. Mancozeb caused 80.67 per cent inhibition in sclerotial germination at $500 \mu \mathrm{g}$ a.i $\mathrm{ml}^{-1}$ followed by captan $50 \mathrm{WP}$ (78.67\%), dodine $65 \mathrm{WP}(70.67 \%)$ and propineb $70 \mathrm{WP}$ $(47.33 \%)$. Completely inhibition of sclerotial germination was caused by mancozeb, captan and dodine at $1000 \mu \mathrm{g}$ a.i ml ${ }^{-1}$ concentration while propineb and zineb caused 61.33 and 50.67 per cent inhibition of sclerotial germination. Copper oxychloride caused lowest inhibition of sclerotial germination of 12.33 per cent at $1000 \mu \mathrm{g}$ a.i $\mathrm{ml}^{-1}$ concentration while no inhibition of sclerotial germination was recorded below this concentration.

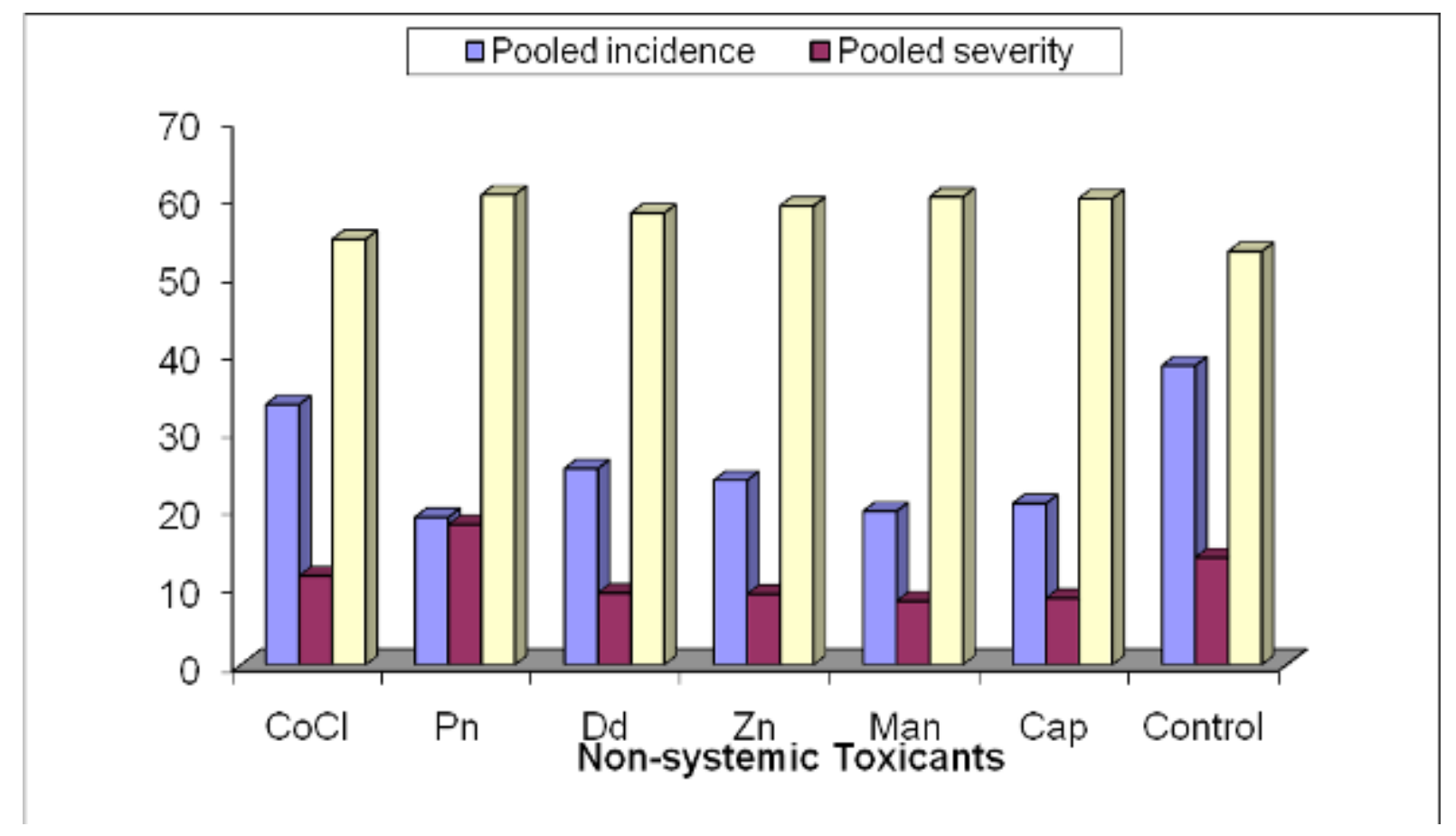


Plate.1 In-vitro evaluation of non-systemic fungitoxicants against Rhizoctonia solani (Clock wise from right bottom; at 0, 50, 100, 250, 500 and1000 $\mu \mathrm{g}^{-1}$ concentration)

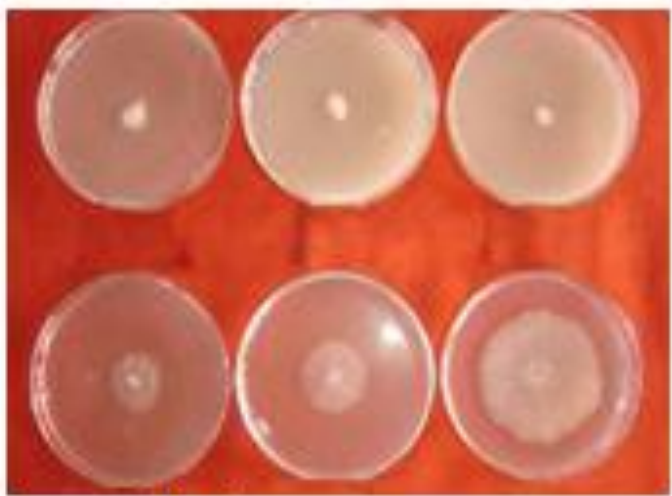

Zineb

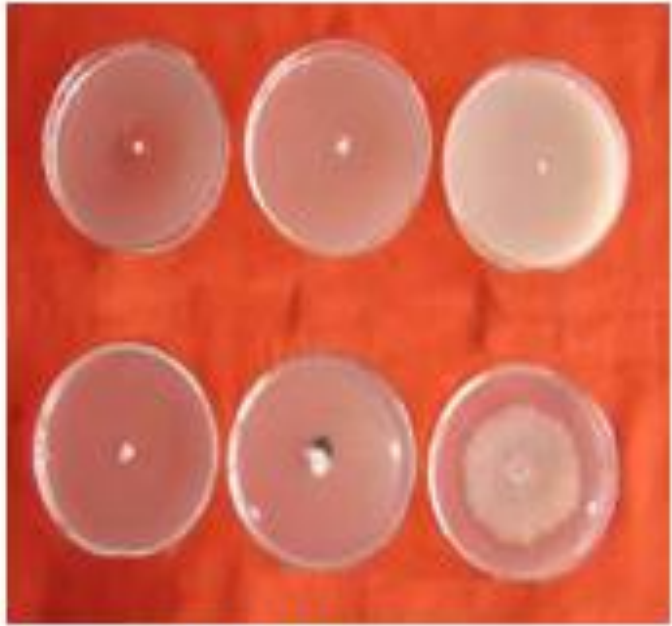

Captan

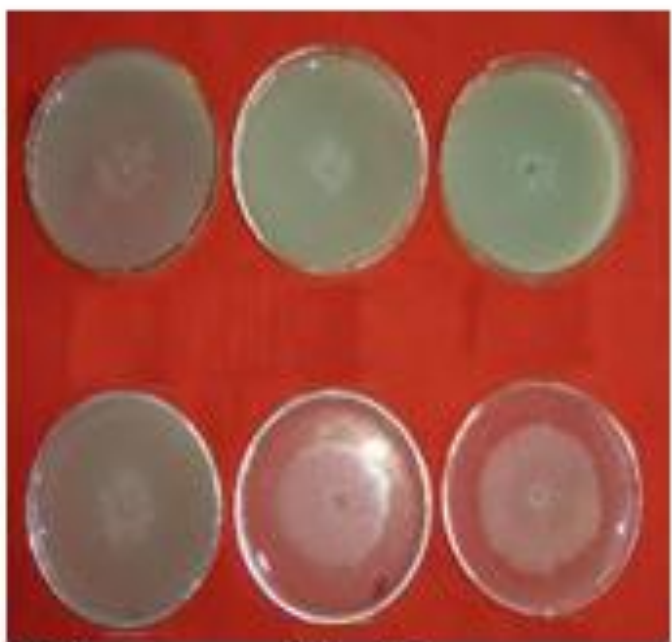

Copper-oxychloride

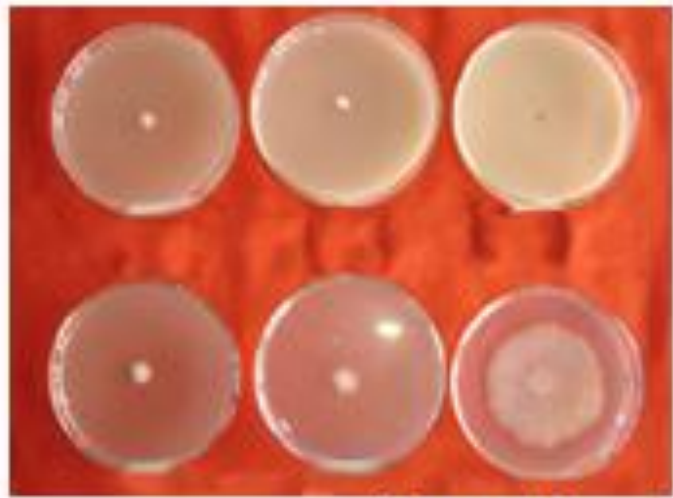

Mancozeb

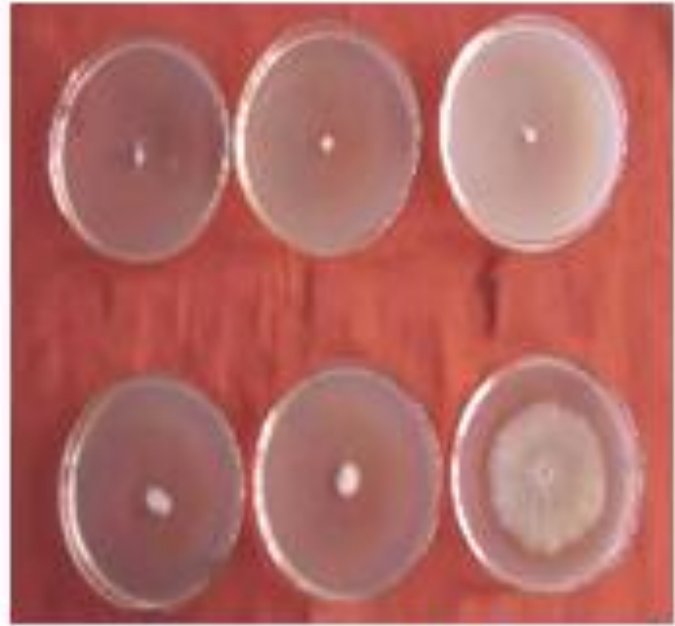

Dodine

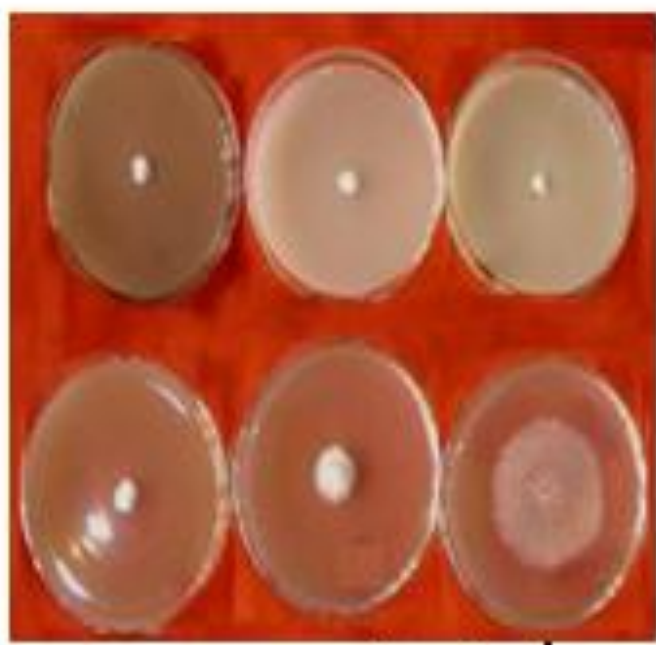

Propineb| 
Table.1 Evaluation of systemic fungicides against inhibition of mycelial growth and sclerotial germination

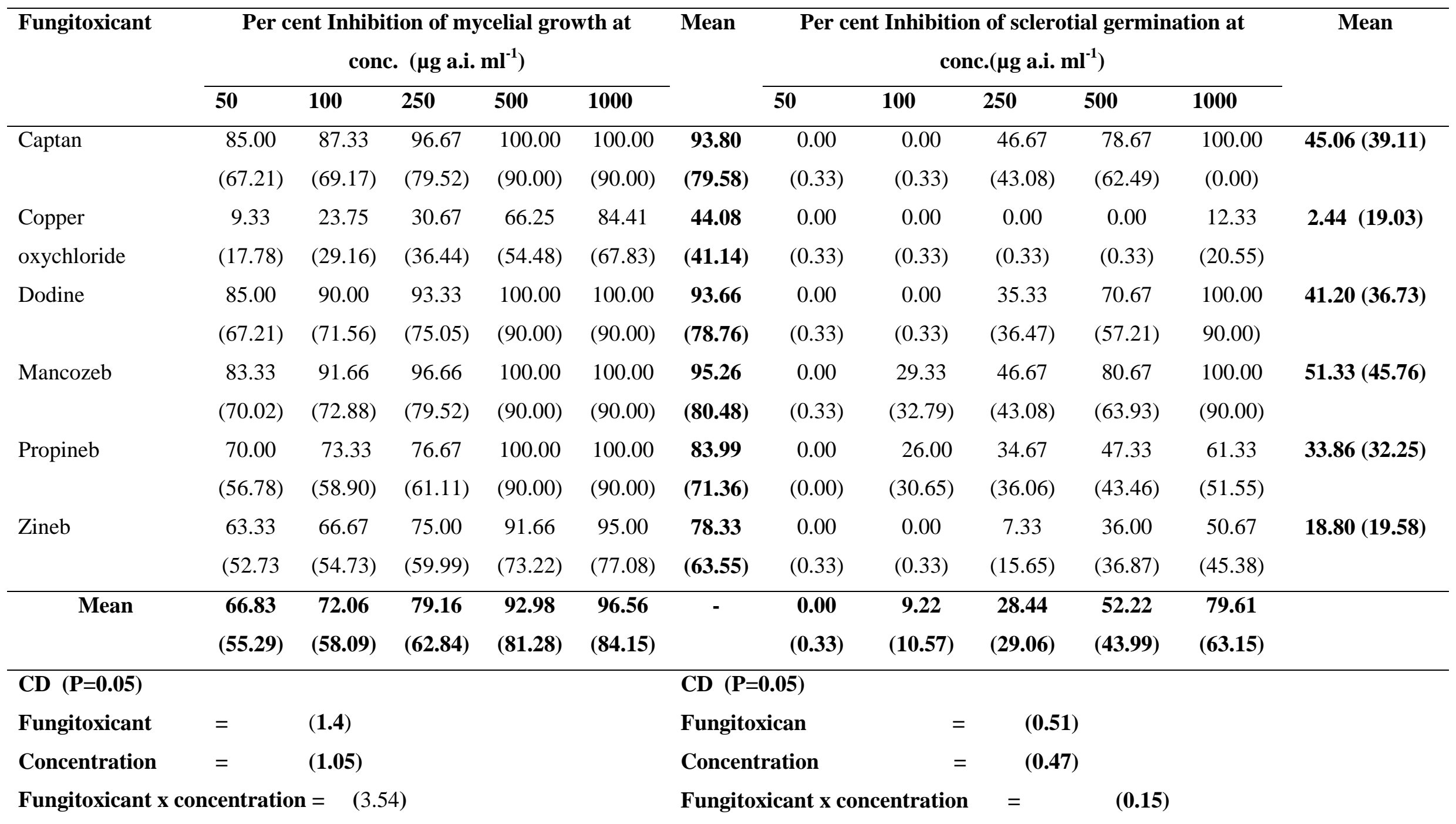

*Mean of three replications; in case of inhibition sclertoial germination 50 sclerotia/replication were observed; Figures within parentheses are angular transformed values 
Int.J.Curr.Microbiol.App.Sci (2017) 6(9): 1824-1832

Table.2 Field evaluation of some non-systemic against rice sheath blight

\begin{tabular}{|c|c|c|c|c|c|c|c|c|c|c|c|}
\hline \multirow[t]{2}{*}{ Fungitoxicant } & \multirow[t]{2}{*}{$\begin{array}{l}\text { Conc. } \\
(\%)\end{array}$} & \multicolumn{2}{|c|}{$\begin{array}{c}\text { Sheath blight incidence } \\
(\%)\end{array}$} & \multirow[t]{2}{*}{ Mean } & \multicolumn{2}{|c|}{$\begin{array}{l}\text { Sheath blight intensity } \\
(\%)\end{array}$} & \multirow[t]{2}{*}{ Mean } & \multicolumn{2}{|c|}{ Yield $\left(\mathrm{t} \mathrm{ha}^{-1}\right)$} & \multirow[t]{2}{*}{ Mean } & \multirow[t]{2}{*}{$\begin{array}{l}\text { Increase in yield } \\
\text { over control (\%) }\end{array}$} \\
\hline & & $I^{\text {st }}$ year & $2^{\text {nd }}$ year & & $I^{\text {st }}$ year & $2^{\text {nd }}$ year & & $I^{\text {st }}$ year & $2^{\text {nd }}$ year & & \\
\hline Captan 50 WP2 & 0.30 & $\begin{array}{c}20.00 \\
(26.54)^{*}\end{array}$ & $\begin{array}{l}22.00 \\
(27.96)\end{array}$ & 21.50 & $\begin{array}{c}8.15 \\
(2.85)^{* *}\end{array}$ & $\begin{array}{l}8.34 \\
(2.88)\end{array}$ & 8.24 & 6.10 & 6.00 & 6.05 & 18.62 \\
\hline $\begin{array}{l}\text { Copper } \\
\text { oxychloride } 50 \mathrm{WP}\end{array}$ & 0.30 & $\begin{array}{c}32.00 \\
(34.44)\end{array}$ & $\begin{array}{c}34.5 \\
(36.16)\end{array}$ & 33.25 & $\begin{array}{l}11.88 \\
(3.44)\end{array}$ & $\begin{array}{l}12.11 \\
(3.47)\end{array}$ & 11.99 & 5.50 & 5.40 & 5.45 & 6.86 \\
\hline Dodine 65 WP3 & 0.06 & $\begin{array}{c}23.5 \\
(28.99)\end{array}$ & $\begin{array}{c}25.00 \\
(29.98)\end{array}$ & 24.25 & $\begin{array}{c}8.03 \\
(2.83)\end{array}$ & $\begin{array}{r}9.08 \\
(3.01)\end{array}$ & 8.55 & 6.00 & 5.90 & 5.95 & 16.66 \\
\hline Mancozeb 75 WP1 & 0.30 & $\begin{array}{c}18.50 \\
(25.45)\end{array}$ & $\begin{array}{c}19.50 \\
(26.17)\end{array}$ & 19.00 & $\begin{array}{c}6.98 \\
(2.64)\end{array}$ & $\begin{array}{c}7.22 \\
(2.68)\end{array}$ & 7.10 & 6.30 & 6.20 & 6.25 & 22.54 \\
\hline Propineb70 WP4 & 0.30 & $\begin{array}{c}24.50 \\
(29.65)\end{array}$ & $\begin{array}{c}26.00 \\
(30.64)\end{array}$ & 25.25 & $\begin{array}{l}9.08 \\
(3.01)\end{array}$ & $\begin{array}{c}9.44 \\
(3.07)\end{array}$ & 9.26 & 5.90 & 5.70 & 5.80 & 13.72 \\
\hline Zineb $80 \mathrm{WP}$ & 0.20 & $\begin{array}{c}25.50 \\
(30.32)\end{array}$ & $\begin{array}{c}28.50 \\
(32.25)\end{array}$ & 27.00 & $\begin{array}{l}9.33 \\
(3.05)\end{array}$ & $\begin{array}{l}10.12 \\
(3.18)\end{array}$ & 9.72 & 5.70 & 5.60 & 5.65 & 10.78 \\
\hline Control & & $\begin{array}{c}39.50 \\
(38.93)\end{array}$ & $\begin{array}{c}40.50 \\
(39.52)\end{array}$ & 40.00 & $\begin{array}{c}18.32 \\
(25.05)\end{array}$ & $\begin{array}{c}19.98 \\
(26.55)\end{array}$ & 19.15 & 5.15 & 5.05 & 5.10 & \\
\hline Mean & & $\begin{array}{r}30.41 \\
(33.32)\end{array}$ & $\begin{array}{c}31.00 \\
(33.56)\end{array}$ & & $\begin{array}{l}10.25 \\
(3.20)\end{array}$ & $\begin{array}{r}10.89 \\
(3.30)\end{array}$ & & & & & \\
\hline & & $\mathrm{SE}_{\mathrm{m}} \pm$ & $\mathrm{CD}(\mathrm{P}=0.05)$ & & $\mathrm{SE}_{\mathrm{m}} \pm$ & $\mathrm{CD}(\mathrm{P}=0.05)$ & & $\mathrm{SE}_{\mathrm{m}} \pm$ & $\mathrm{CD}(\mathrm{P}=0.05)$ & & \\
\hline $\begin{array}{ll}\text { Botanical } & = \\
\text { Year } & =\end{array}$ & & 1.07 & 2.14 & & 0.62 & 1.21 & & 0.12 & 0.25 & & \\
\hline $\begin{array}{l}\text { Botanical } \times \\
\text { Year }=\end{array}$ & & & & & & & & & & & \\
\hline
\end{tabular}

*Figure in the parenthesis are arc sin transformed; ** figures in parenthesis are sqrt transformed 


\section{Field evaluation of fungicides}

Persual of data (Table 2) revealed that on an overall basis, mancozeb 75 WP was most effective fungicide reducing the disease incidence and disease intensity to 19.00 and 7.10 per cent from 40.00 and 19.15 per cent, respectively, in unsprayed check, and increasing the yield from $5.25 \mathrm{t} \mathrm{ha}^{-1}$ in unsprayed check to $6.25 \mathrm{t} \mathrm{ha}^{-1}$. Captan $50 \mathrm{WP}$ was the next in efficacy, reducing disease incidence and disease intensity to 21.50 and 8.24 per cent, respectively and resulting in a grain yield of $6.10 \mathrm{tha}^{-1}$. The other fungicides in order of their decreasing efficacies on the basis of their overall performance during two years of experimentation were dodine $65 \mathrm{WP}$, propineb $70 \mathrm{WP}$ and zineb $80 \mathrm{WP}$ with mean disease incidence of 24.25, 25.25 and 27.00 per cent and mean disease intensity of 8.55 , 9.26 and 9.72 per cent, and grain yield of $5.95,5.80$ and $5.65 \mathrm{t} \mathrm{ha}^{-1}$, respectively. Copper oxychloride 50 WP proved least efficacious, exhibiting mean disease incidence 33.25, mean disease intensity of 11.99 per cent and a grain yield of $5.45 \mathrm{tha}^{-1}$.

Mancozeb 75 WP resulted in highest (19.04) increase in grain yield over check followed by captan 50 WP (15.45), while dodine 65 WP and propineb $70 \mathrm{WP}$ and zineb $80 \mathrm{WP}$ resulted in 13.33, 10.47 and 7.61 per cent increase in grain yield, respectively. Copper oxychloride, though least efficacious among the tested fungicide, was superior to check and increased the grain yield by 3.80 per cent.

The efficacy of mancozeb $75 \mathrm{WP}$ against rice sheath blight of rice has been reported Roy and Sakia (1976). Suryadai and Kadier (1989) found chlorothalonil, mancozeb and mancozeb + zineb most effective in checking the sheath blight of rice. While Jana et al., 1989, reported the application of Dithane M45(mancozeb 75 WP) as most effective in reducing the sheath blight of rice. Biswas
(2005) reported the efficacy of propineb 70 WP for management of rice sheath blight.

Though sole dependence on chemical fungicides should not be encouraged because of long residual properties, non-target action, biological magnification and pollutant dangers but they cannot be ignored all at once unless some potential alternatives are found. Since rice grains are milled before use/cooking, the non-systemic fungicides which form the protective layers does have least chance of penetration in rice grains and thereby in the food chain of humans and therefore, their use is comparative safer than the fungicides which entre into the system of rice plant and rice grains which may result in health hazards. The present situation demands their incorporation in the integrated disease management schedule for better disease management and optimum returns from crop husbandry.

\section{References}

Baby, U.I., 1992. Studies on the control of rice sheath blight through the integration of fungal antagonists and organic amendments. Tropical Agriculture 70: 240-244

Biswas, A., 2005. Evaluation of some commercially available fungicides against sheath blight disease of rice. Journal of Mycopathological Research 43(1): 141-142

Carpenter, J.B., 1942. A toximetric study of some eradicant fungicides. Phytopathology 32: 845.

Eizenga, G.C., Lee, F.N. and Rutger, J.N., 2002. Screening Oryza species plants for rice sheath blight resistance. Plant Disease 66: 808-812.

Jana, B.K., Laha, S.K. and Khatua, D.C., 1989. Leaf blight caused by $R$. solani and its control. Pesticides 23: 33-34.

Kaloo, M J., Patidar, R and Choure, T., 2014. 
Production and Productivity of Rice in Jammu and Kashmir: An Economic Analysis. International Journal of Research 1: 2348-6848

Mir, N.M., 1986. Important Diseases of Rice: Rice Production Training Programme Manual. 23-26. June Regional Rice Research Station, SKUAST, Khudwani

Ou, S.H., 1992. Rice Diseases. Commonwealth Mycological Institute, Kew, England, p. 368 Journal of Mycopathological Research. 51: 189191

Paracer, C.S., and Chahal, D.S., 1963. Sheath blight of rice caused by Rhizoctonia solani Kühn, a new record in India. Current Science 32:320-329.

Rajan, C.P.D., 1987. Estimation of yield losses due to sheath blight disease of rice. Indian Phytopathology 40: 174177.

Ramakrishnanan, T.S., 1971. Diseases of rice. Indian Council of Agriculture Research, New Delhi p. 150.

Roy, A.K., and Saikia, U.N., 1976. Chemical control of sheath blight of rice. Indian Phytopathology 29: 354-356.

Suryadi, Y., and Kadir, T.S., 1989. Field evaluation of fungicides to control rice sheath blight. International Rice Research Newsletter 14: 35.

Vihol, J.B., Patel K. D., Jaiman R. K and Patel N.R., 2009. Efficacy of plant extracts, biological control agents and fungicides against Alternaria blight of cumin. Journal of Mycology and Plant Pathology 39(3):516-519

\section{How to cite this article:}

Mohammad Najeeb Mughal, Mushtaq Ahmed, Sabiya Bashir, Ali Anwar, Serrat un Nissan, Rais Ahmed and Shafeeq Ahmed Hakeem. 2017. Comparative Efficacy of Some Non Systemic Fungicides against Rice Sheath Blight (Thanatephorus cucumeris). Int.J.Curr.Microbiol.App.Sci. 6(9): 1824-1832. doi: https://doi.org/10.20546/ijcmas.2017.609.225 